\title{
Ecological sanitation a new approach to protect public health and environment in rural areas of Morocco
}

\author{
Aziz Taouraout ${ }^{1,2, *}$, Abdelkader Chahlaoui ${ }^{2}$, Khadija Ouarrak $^{2}$, Hicham Aaziz $^{3}$, Driss Belghyti ${ }^{1}$ \\ ${ }^{1}$ Laboratory of Agrophysiology, Biotechnology, Environment and Qualities, Faculty of Sciences, University IbnTofail of Kenitra, \\ BP: 133, 14000 Kenitra Morocco. \\ ${ }^{2}$ Laboratory of Natural Resources Management and Development Team, Health and Environment, Faculty of Science, Moulay Ismail \\ University Meknes, Morocco. \\ ${ }^{3}$ Laboratory of Applied Organic Chemistry. Faculty of Sciences and Techniques, Sidi Mohamed Ben Abdellah University Fez, \\ Morocco., Morocco
}

\begin{abstract}
Wastewater and human excreta are threatening the quality of groundwater and watercourses in rural areas of Morocco. The new sanitation approach that has advantage to solve the problems of pathogens of human waste at source and offering the possibility of reusing them after treatment is called Ecological Sanitation (EcoSan) could be an alternative solution to the conventional one.

It is in this perspective that our study made an investigation on economic, ecological, sustainable sanitation techniques adapted to the Moroccan context. Indeed, a survey was carried out at Dayet Ifrah village to assess the population appreciation of the EcoSan structures installed. Survey results showed that these structures have been generally accepted by almost all users and non-users $(95 \%)$.

On the other hand, a pilot-scale system composed by two types of filters (vertical constructed wetland and vertical Multi-Soil-Layering) have been installed in order to treat domestic wastewater coming from a single household and their performance was evaluated. The filters showed good performance to remove organic pollution $(>84.5 \%)$ and orthophosphate $(>68 \%$ ). The reduction of ammonium were $84.5 \%$ and $35.3 \%$ for vertical Multi-Soil-Layering and vertical constructed wetland, respectively. The quality of the wastewater treated was evaluated in accordance with the standard of the rejection limit value adopted by Morocco.
\end{abstract}

\section{Introduction}

Rural areas of Morocco still do not have access to an adequate sanitation. Indeed, the proportion of households with access to a sewage sewerage system is only $2.8 \%$ in 2014. The share of the rural population with access to an improved sanitation system (with septic tanks) increased from $38.1 \%$ in 2004 to $53.3 \%$ in 2014 [1]. Indeed, the population generally uses traditional pit latrines and practices the direct discharge of gray water into nature without treatment [2].

With the increase in the supply of drinking water in recent years (97\%), the amount of wastewater generated is very large. Unfortunately, open defecation remains the only way for the population without toilets [2-3]. These practices still present a major risk for public health and the environment; exposing many people to infection and dangerous diseases [4-6]. Indeed, human excrement presents a high risk because it can contain pathogens such as bacteria and parasites capable of causing diarrheal diseases (cholera, typhoid, etc.) [7].

In order to overcome these problems the first step that Morocco has taken is the implementation of a National Rural Sanitation Plan (PNAR). Its main objective is the promotion of sanitation in rural areas by investigating ecological and economical techniques adopted in Moroccan context. The second step was the adoption of the Law No. 36.15. This law established mechanisms for the protection and preservation of water resources, and includes provisions to improve the protection conditions against extreme events related to climate change.

The first pilot project of Ecological Sanitation (EcoSan) was introduced in a rural village called 'Dayet
Ifrah' (Ifran region) in December 2009. This village is chosen to be the pilot site of the EcoSan project because, first, it lacked sanitation infrastructure that a Moroccan village could face; second, it is part of the "Ifrane Natural Park" area to be protected [8]. The structures installed in this Ecosan pilot project are Urine Diversion Dehydration Toilets (UDDT) and Horizontal Constructed Wetlands (HCW).

This study aims to:

- Give the main results of the survey that we were carried out in this village in 2017 concerning the evaluation of the socio-cultural acceptance and the degree of appreciation of this new concept of sanitation among the population.

- Evaluate the performance of a pilot scale system composed by a Vertical Constructed Wetland (VCW) and a Vertical Multi-Soil-Layering (V-MSL) used to treat domestic wastewater coming from a single household in Meknes.

\section{Materiel and methods}

\subsection{Survey}

In order to judge perception and attitude of the population towards EcoSan structures installed in the village of Dayet Ifrah, a survey was carried out in 2017. Several techniques and data collection tools were used in this study. The qualitative and quantitative data were collected through field observation, a survey, a group discussion and interviews [2,9].

\subsection{Description of pilot scale system}

\footnotetext{
*Corresponding author: aziz.taouraout@uit.ac.ma
} 
The pilot scale system used in this study is composed by a Vertical Constructed Wetland (VCW) $(0.6 \mathrm{~m} \mathrm{~L} \times 0.4$ $\mathrm{m} \mathrm{W} \times 0.78 \mathrm{~m} \mathrm{H})$ and a Vertical Multi-Soil-Layering (VMSL) $(0.6 \mathrm{~m} \mathrm{~L} \times 0.2 \mathrm{~m} \mathrm{~W} \times 0.78 \mathrm{~m} \mathrm{H})$. This system was feeding with a tank (100L) used to store prescreened wastewater coming from a single household using a submersible pump. The main characteristics of this system are summarized in Table 1 .

Table 1. Main characteristics of the pilot unit.

\begin{tabular}{|l|c|c|}
\hline \multicolumn{1}{|c|}{ Caracteristics } & VCW & V-MSL \\
\hline Area $\left(\mathrm{m}^{2}\right)$ & 0.24 & 0.12 \\
\hline $\begin{array}{l}\text { Dimensions } \\
(\text { LxWxH })\end{array}$ & $0.40 \times 0.60 \times 0.78$ & $0.20 \times 0.60 \times 0.78$ \\
\hline Feeding type & $\begin{array}{c}\text { Alternate and } \\
\text { sequenced }\end{array}$ & Discontinued \\
\hline Flow direction & Vertical & Vertical \\
\hline Aeration & Yes & Yes \\
\hline Medium & $\begin{array}{c}\text { Unsaturated } \\
\text { and aerobic }\end{array}$ & $\begin{array}{c}\text { Aerobic } / \\
\text { anaerobic }\end{array}$ \\
\hline Plantation & Yes & No \\
\hline
\end{tabular}

The choice of materials used in our system, is mainly related to their availability and cost in Morocco. The VMSL is composed by six permeable layers (PLs) with gravel (diameter between 3 to $5 \mathrm{~mm}$ ), five Soil-MixtureBlocs (SMBs). The SMBs measuring $20 \mathrm{~cm}$ (L) x $16.5 \mathrm{~cm}$ (W) x $4 \mathrm{~cm}(\mathrm{H})$, are composed by $60 \%$ of soil, $10 \%$ of charcoal, $10 \%$ of iron sawdust and $20 \%$ of wood sawdust (Fig. 1). While the VCW is composed by gravel, iron sawdust and crushed concrete (Fig. 1). Crushed concrete and iron sawdust were used for the first time in constructed wetland filter in order to enhance the adsorption of phosphate [10].

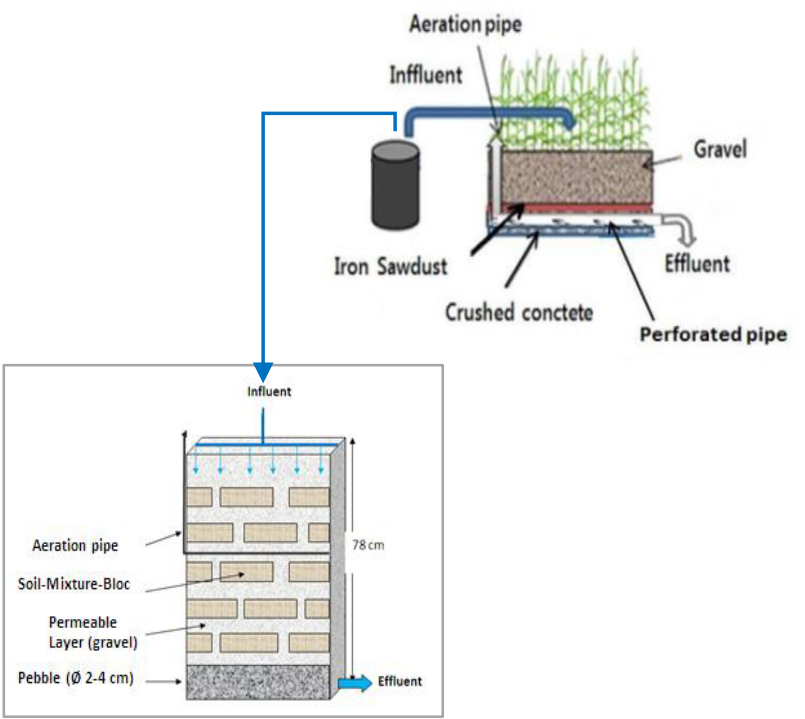

Fig. 1. Schematic representation of pilot scale system

\subsection{Analyzes carried out}

Samples of raw and treated water were collected at the same time each month (from June until November 2017) and analyzed for different water quality parameters using the French standard methods [11]. Multiparameter probe type PCE-PHD1 is used to measure temperature (T), $\mathrm{pH}$, and Dissolved Oxygen (DO) and turbidity is measured by Turbidity meter (HI 93703 HANNA instruments). In addition, Biochemical oxygen demand $\left(\mathrm{BOD}_{5}\right)$ was determined by the BOD Sensor (VELP SCIENTIFICA), chemical oxygen demand (COD) was analyzed according to the dichromate open reflux method and Total Suspended Solids (TSS) concentration was determined by the filtration method. While, Ammonium $\left(\mathrm{NH}_{4}^{+}\right)$ concentration was determined by the indophenol method, and orthophosphate $\left(\mathrm{PO}_{4}{ }^{3-}\right)$ concentration by the molybdate and ascorbic acid method.

\subsection{Data analysis}

Statistical analyses of the collected data were carried out using software: Microsoft Excel and SPSS (Analysis of variance test (ANOVA)).

\section{Results and discussions}

\subsection{Survey results}

Survey result shows that around $94 \%$ of households with of the UDDT expressed their satisfaction because it provides shelter to hide their privacy and safety in cold weather and at night especially for women and children. In addition, $65 \%$ of people surveyed master the UDDT using. More than that, $85 \%$ of the surveyed population gave their agreement for the adoption of the UDDT in the event of the extension of the project. Furthermore, $80 \%$ of those who have traditional toilets want to convert them to dry toilets for the following reasons: reduced water consumption by using ashes instead of flushing, odorless...(Fig.2).

On the other hand, the population gives an important place to the maintenance of their eco-toilets since the frequency of their cleaning is particularly high (2 to 3 times per week). This shows that people are adhering to the logic of improving their living environment and protecting their environment. In addition, most people respondents recommend the generalization of this type of toilet for the entire population of the village and for all Moroccan rural areas [2].

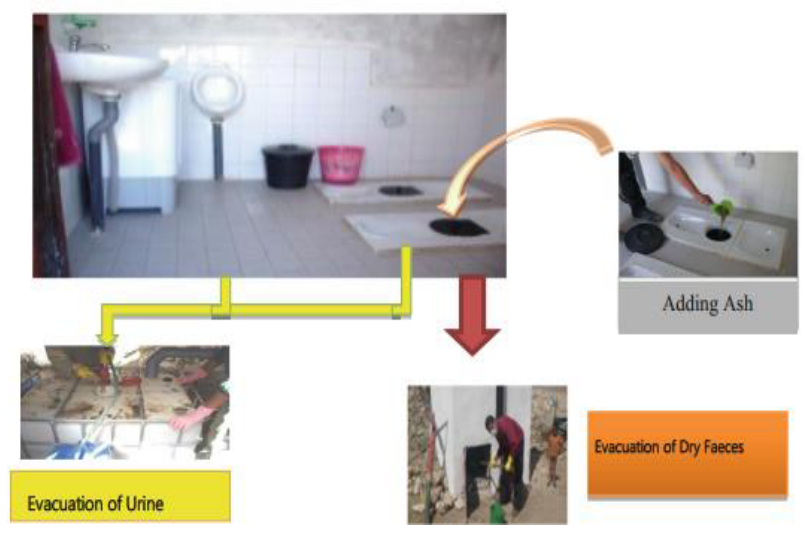

Fig. 2. UDDT installed at Dayet Ifrah Village 
The main results of this study show a real change in habits hygiene and sanitation after the introduction of EcoSan structures in this village. According to the survey, the beneficiaries of the project are generally satisfied with the services provided by these structures. Thus, it is clear that EcoSan latrines meet the expectations of beneficiaries, because around $95 \%$ positively appreciate this system. This population believes that EcoSan structures offer a safe sanitation solution that prevents disease and promotes health by successfully and hygienically removing pathogen-rich excreta from the immediate environment, avoid contamination of groundwater and preserve the use of scarce water resources.

\subsection{Domestic wastewater treatment}

\subsubsection{Concentrations of general parameters}

The results in Table 2 show that the average values of temperature, $\mathrm{pH}$ and electrical conductivity in outlet of the filters are almost similar to those of the raw water. However, the mean values of turbidity in effluent are four times reduced compared to those in influent. In addition, dissolved oxygen concentrations were higher in outlet of the VCW and V-MSL filters with $(4.5 \pm 0.5) \mathrm{mg} / \mathrm{L}$ and $(4.3 \pm 0.6) \mathrm{mg} / \mathrm{L}$, respectively; against only $(1.2 \pm 0.5)$ $\mathrm{mg} / \mathrm{L}$ for the raw water.

Table 2. Temperature, $\mathrm{pH}, \mathrm{EC}$, turbidity and DO values

\begin{tabular}{|l|l|l|l|l|l|}
\hline & $\begin{array}{l}\mathbf{T} \\
\left({ }^{\circ} \mathbf{C}\right. \\
\mathbf{0}\end{array}$ & $\mathbf{p H}$ & $\begin{array}{l}\mathbf{E C} \\
\mathbf{( m S / c m}\end{array}$ & $\begin{array}{l}\text { Turbidit } \\
\mathbf{y}\end{array}$ & $\begin{array}{l}\mathbf{D O} \\
\mathbf{( m g / L )}\end{array}$ \\
\hline $\begin{array}{l}\text { Influen } \\
\mathrm{t}\end{array}$ & $\begin{array}{l}20 . \\
9\end{array}$ & $7 \pm 0.6$ & $\begin{array}{l}1.21 \pm 0 . \\
4\end{array}$ & $84.7 \pm 17$ & $\begin{array}{l}1.2 \pm 0 . \\
5\end{array}$ \\
\hline VCW & $\begin{array}{l}20 . \\
3\end{array}$ & $\begin{array}{l}7.4 \pm 0 . \\
2\end{array}$ & $\begin{array}{l}0.87 \pm 0 . \\
2\end{array}$ & $17.9 \pm 9.6$ & $\begin{array}{l}4.5 \pm 0 . \\
5\end{array}$ \\
\hline $\begin{array}{l}\text { V- } \\
\text { MSL }\end{array}$ & $\begin{array}{l}20 . \\
6\end{array}$ & $\begin{array}{l}7.3 \pm 0 . \\
3\end{array}$ & $\begin{array}{l}1.03 \pm 0 . \\
1\end{array}$ & $19.8 \pm 6.5$ & $\begin{array}{l}4.3 \pm 0 . \\
6\end{array}$ \\
\hline
\end{tabular}

\subsubsection{Concentration of organic pollution}

The mean concentrations of $\mathrm{BOD}_{5}, \mathrm{COD}$ and TSS at the inlet and outlet of the filters during the study period were respectively, $(198.6 \pm 50.2) \mathrm{mg} / \mathrm{L},(413.3 \pm 100.1)$ $\mathrm{mg} / \mathrm{L}$ and $(372.5 \pm 103.2) \mathrm{mg} / \mathrm{L}$ for influent; $(29.5 \pm$ $12.1) \mathrm{mg} / \mathrm{L},(56.8 \pm 23.4) \mathrm{mg} / \mathrm{L}$ and $(47.5 \pm 28) \mathrm{mg} / \mathrm{L}$ for VCW and $(30.1 \pm 8.2) \mathrm{mg} / \mathrm{L},(61.2 \pm 16.5) \mathrm{mg} / \mathrm{L}$ and (58.2 \pm 41.6$) \mathrm{mg} / \mathrm{L}$ for V-MSL (Fig. 2).
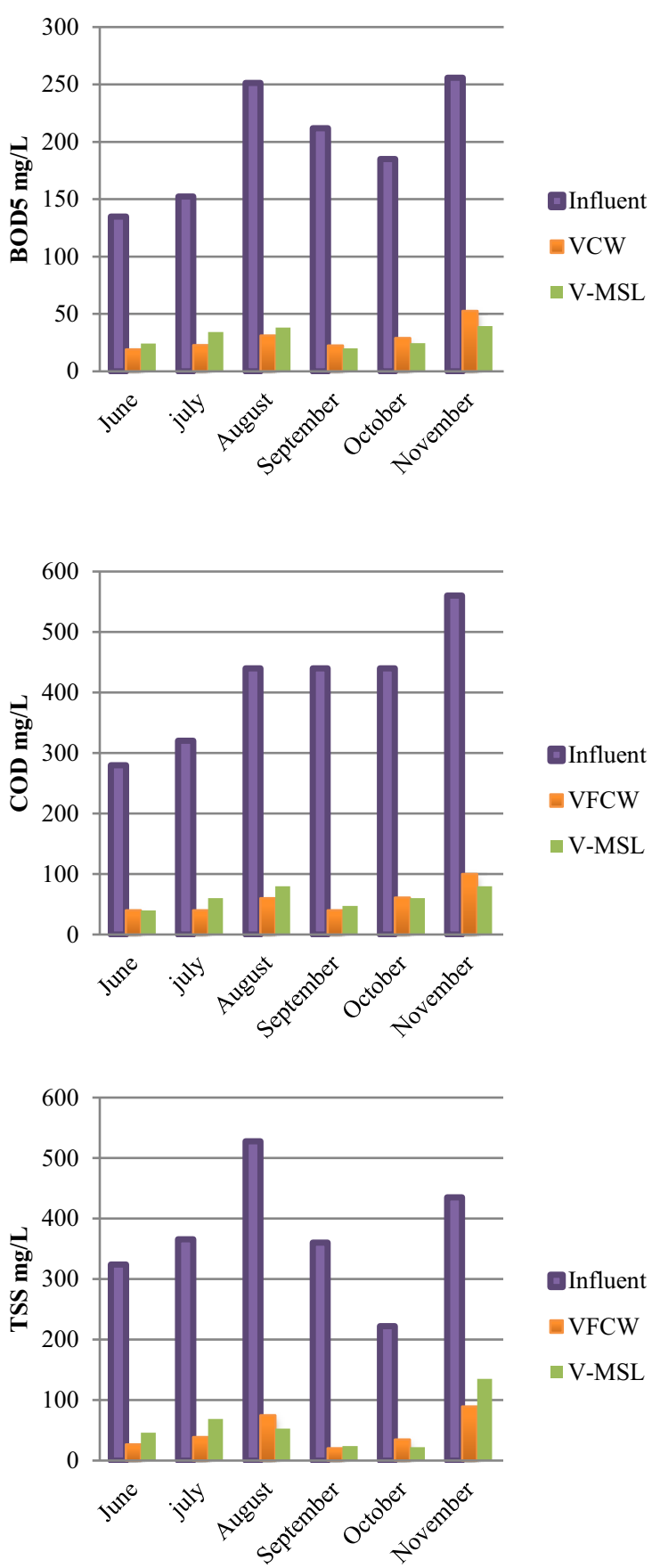

Fig. 21. Concentration of organic pollution

The ANOVA test shows that there is a significant difference between the BOD, COD and TSS averages in influent and effluent at $p<0.001$. However, this test did not show any significant difference between VCW and VMSL (Table 3).

Table 3. Analysis of variance (ANOVA) of the organic pollution concentrations

\begin{tabular}{|l|l|l|c|c|}
\hline Variable & $\begin{array}{c}(\mathbf{I}) \\
\text { Treatment }\end{array}$ & $\begin{array}{c}(\mathbf{J}) \\
\text { Treatment }\end{array}$ & $\begin{array}{c}\text { Difference } \\
(\mathbf{I}-\mathbf{J})\end{array}$ & $\begin{array}{c}\text { Signification } \\
(\mathbf{p})\end{array}$ \\
\hline $\begin{array}{l}\text { BOD5 } \\
(\mathrm{mg} / \mathrm{L})\end{array}$ & \multirow{2}{*}{ Influent } & VCW & $169,10^{* * *}$ & 0,000 \\
\cline { 3 - 5 } & V-MSL & $168,53^{* * *}$ & 0,000 \\
\hline
\end{tabular}




\begin{tabular}{|l|l|l|r|r|}
\hline & VCW & V-MSL & $-0,566$ & 0,999 \\
\hline \multirow{2}{*}{$\begin{array}{l}\mathrm{COD} \\
(\mathrm{mg} / \mathrm{L})\end{array}$} & \multirow{2}{*}{ Influent } & VCW & $356,50^{* * *}$ & 0,000 \\
\cline { 2 - 5 } & VCW & V-MSL & $352,16^{* * *}$ & 0,000 \\
\hline \multirow{2}{*}{$\begin{array}{l}\mathrm{TSS} \\
(\mathrm{mg} / \mathrm{L})\end{array}$} & \multirow{2}{*}{ Influent } & VCW & $-4,33333$ & 0,992 \\
\cline { 2 - 5 } & VCW & V-MSL & $325,06^{* * *}$ & 0,000 \\
\cline { 2 - 5 } & V-MSL & $-10,68$ & 0,000 \\
\hline
\end{tabular}

*** Signification at $\mathrm{p}<0,001 ; \quad \mathrm{VCW}$ : vertical constructed wetland V-MSL: Vertical Multi-Soil-Layering; I and J: concentrations of a specified variable
Table 4. Analysis of variance (ANOVA) of the nutrient concentrations

\begin{tabular}{|c|c|c|c|c|}
\hline Variable & \begin{tabular}{c|} 
(I) \\
Treatment
\end{tabular} & $\begin{array}{c}(\mathbf{J}) \\
\text { Treatment }\end{array}$ & $\begin{array}{l}\text { Difference } \\
\text { (I-J) }\end{array}$ & Sig. (p) \\
\hline \multirow{3}{*}{$\mathrm{NH}_{4}^{+}$} & \multirow{2}{*}{ Influent } & $\mathrm{VCW}$ & $6,53333 * *$ & 0,002 \\
\hline & & V-MSL & $15,86667 * * *$ & 0,000 \\
\hline & VCW & V-MSL & $9,33333 * * *$ & 0,000 \\
\hline \multirow{3}{*}{$\mathrm{PO}_{4}^{3-}$} & \multirow{2}{*}{ Influent } & VCW & $2,55000 * * *$ & 0,000 \\
\hline & & V-MSL & $2,50500 * * *$ & 0,001 \\
\hline & VCW & V-MSL & $-0,04500$ & 0,996 \\
\hline
\end{tabular}

\subsubsection{Concentration of nutrients}

The mean concentrations of $\mathrm{NH}_{4}{ }^{+}$and $\mathrm{P}_{4}{ }^{3-}$ at the inlet and outlet of the filters during the study period were respectively, $(18.8 \pm 3.2) \mathrm{mg} / \mathrm{L}$ and $(3.7 \pm 1.3) \mathrm{mg} / \mathrm{L}$ for influent; $(12.2 \pm 2.8) \mathrm{mg} / \mathrm{L}$ and $(1.2 \pm 0.5) \mathrm{mg} / \mathrm{L}$ for $\mathrm{VCW}$ and $(2.9 \pm 0.9) \mathrm{mg} / \mathrm{L}$ and $(1.2 \pm 0.5) \mathrm{mg} / \mathrm{L}$ for $\mathrm{V}$ MSL (Fig. 3).

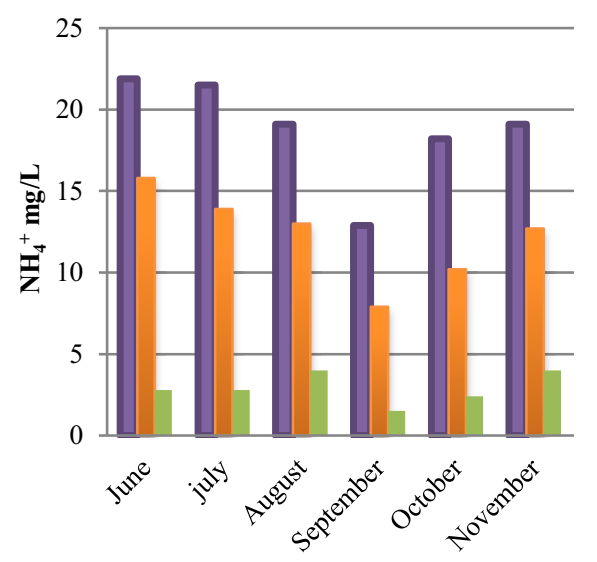

DInfluent

$\square \mathrm{VFCW}$

$\because \mathrm{V}-\mathrm{MSL}$

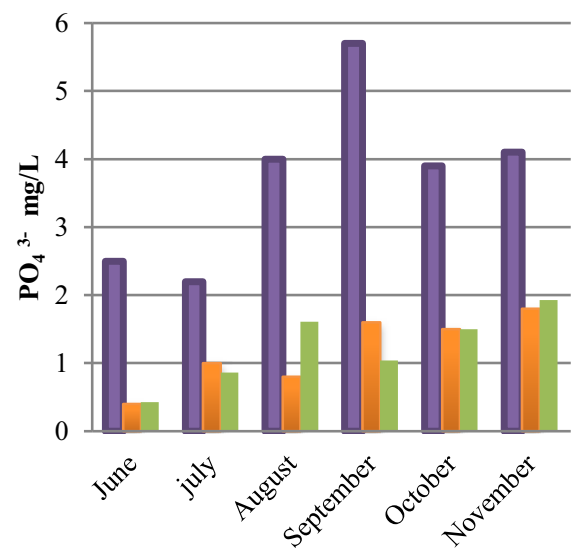

DInfluent

$\square \mathrm{VFCW}$

$\square \mathrm{V}-\mathrm{MSL}$

The ANOVA test shows that there is a significant difference between the $\mathrm{P}_{4}{ }^{3-}$ concentrations in influent and effluent at $\mathrm{p}<0.001$. However, this test ANOVA did not show any significant difference of the $\mathrm{P}_{4^{3-}}{ }^{3-}$ concentrations between VCW and V-MSL (Table 4). On the other hand, the ANOVA test shows a very highly significant difference between the $\mathrm{NH}_{4}{ }^{+}$concentrations in influent and V-MSL and between VCW and V-MSL; while it shows only a highly significant difference between influent and VCW $(\mathrm{p}<0.01)$ (Table 4).

\subsection{Reduction of $\mathrm{BOD}_{5}, \mathrm{COD}$ and TSS}

The average removal of $\mathrm{BOD}_{5}, \mathrm{COD}$ and TSS by the VCW and V-MSL were respectively, $85.3 \pm 3.4 \%$, $86.4 \pm 2.8 \%$ and $87.5 \pm 5.4 \%$ for the VCW and $84.5 \pm 4.7 \%, 85 \pm 2.9$ and $84.8 \pm 8.8 \%$, with the V-MSL (Fig.4). The high rates of elimination of organic pollution are linked to the sedimentation of suspended solids and the processes of rapid decomposition by microorganisms in the top layer of both VMSL and VCW filters [12-14].

On the other hand, the average abatement of $\mathrm{NH}_{4}{ }^{+}$by the V-MSL was very high $84.5 \pm 4.3 \%$ against only $35.3 \pm 5.7 \%$ for VCW. However, these filters showed both a good performance to reduce $\mathrm{P}_{4}{ }^{3-}$ with an average of $68 \%$. The ANOVA test shows that there is a highly significant difference of $\mathrm{NH}_{4}{ }^{+}$abatement between VCW and V-MSL $(\mathrm{p}<0.01)$. However, this test did not show any significant difference to reduce $\mathrm{P}_{4}{ }^{3-}$ between $\mathrm{VCW}$ and V-MSL.

Fig. 32. Concentration of nutrients 

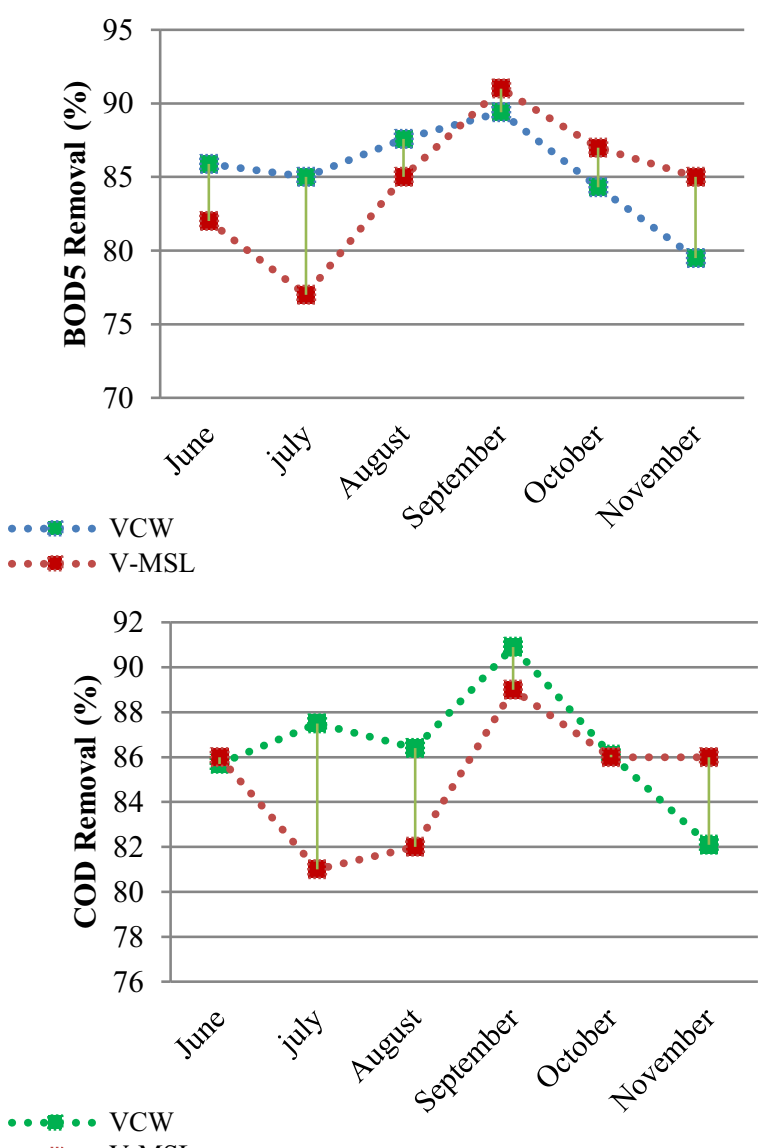

$\cdots \cdot$ V-MSL
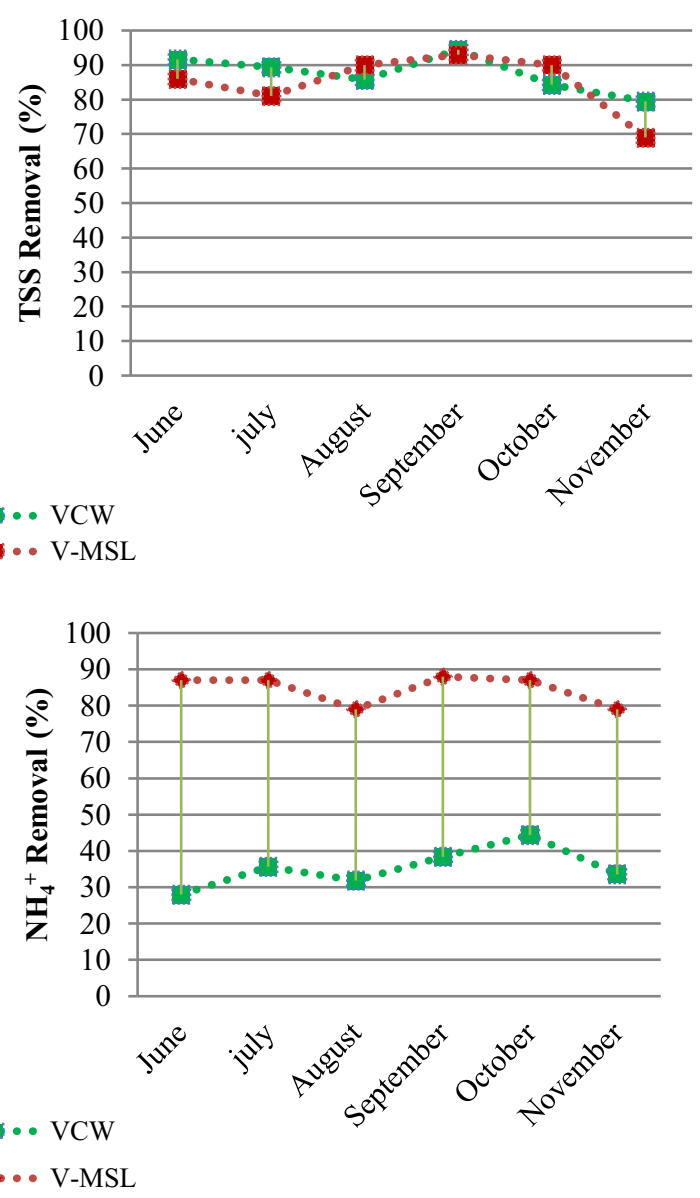

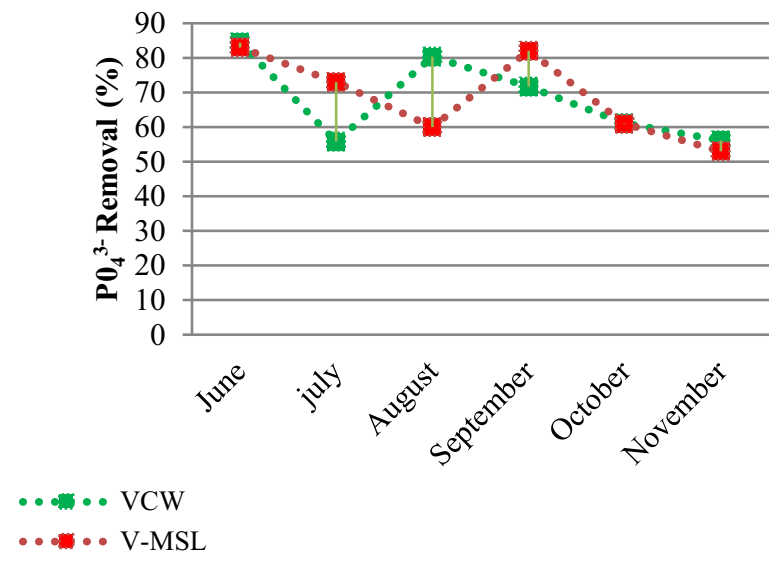

Fig. 43. Reduction of organic pollution and nutrients

These results are superior to those reported by Molle et al. [15] in terms of reduction of COD and TSS, which were $68 \%$ and $74 \%$ respectively and those reported by Vera et al. [16] with $80 \%$ and $75 \%$ for COD and $\mathrm{BOD}_{5}$ for VCW . Morvannou et al. [17], Paing et al. [18] and Morari \& Giardini [19] reported similar results than ours.

In addition, Abou-Elela \& Hellal [20] reported the following results $(88 \%, 90 \%, 92 \%, 53 \%$ and $57 \%$ respectively) for $\mathrm{COD}, \mathrm{BOD}_{5}$, TSS, total nitrogen and ammonium on a VCW large-scale system in Egypt. Molle et al. [21] presented an overview of the performance of the VCW French system in two stages, with rates removal greater than $90 \%$ for COD, $94 \%$ for SS and $85 \%$ for TKN, while that the respective values of the first treatment were $79 \%, 86 \%$ and $58 \%$.

\section{Conclusion}

The good performances obtained by the V-MSL and VCW in this pilot scale study indicate that these filters are adapted to the Moroccan context since they are economic and ecological systems. The quality of the treated domestic wastewater is in line with Morocco's discharge standards. If we are interested only in gray water treatment, the results will be better. Consequently, gray water treated by this system could be reused for irrigation or toilet flushing.

In order to protect public health and environment against fecal pollution and parasites, we recommend adoption of ecological sanitation approach which based on treatment of excreta at source by using of dry toilets (UDDT) and treated gray water only by using the V-MSL or VCW filter.

\section{References}

1. High Commissioner of Planning. General Census of Population and Housing in Morocco (2014).

2. A. Taouraout, A. Chahlaoui, D. Belghity, M. Najy; A. Kharroubi (2018). The socio-cultural acceptance of EcoSan latrines (UDDTs) in rural areas of Morocco. 
SCA '18, October 10-11, 2018, Tetouan, Morocco (C) 2018 Association for Computing Machinery. ACM ISBN $\quad 978-1 \quad-4503-6562-8 / 18 / 10 \ldots \$ 15.00$. https://doi.org/10.1145/3286606.3286815

3. WHO/UNICEF. Drinking Water,Sanitation and HygieneUpdate and SDG Baselines. Report (2017).

4. J.N. Galloway, F.J.Dentener, D.G. Capone, E.W. Boyer, R.W.Howarth, S.P.Seitzinger, G.P.Asner, C.C. Cleveland, P.A. Green, E.A. Holland,Nitrogen cycles: past, present, and future. Biogeochemistry; 70:153226 (2004).

5. RT. Watson, AH. Zakri,. Living beyond our means. Natural assets and human well-being. Statement from the Board. Millennium Ecosystem Assessment (2008).

6. United Nations. Agenda items 5, 6 and 18 (a) High level segment High-level political forum on sustainable development, convened under the auspices of the Economic and Social Council Economic and environmental questions: sustainable development Progress towards the Sustainable Development Goals. Report of the Secretary-General (2016).

7. OMS, Directives de l'OMS sur la réutilisation des eaux usées, des excréta et des eaux grises (2006).

8. Y. Abarghaz, Assainissement écologique rurale Projet pilote du douar de Dayet Ifrah. Master en génie et gestion de $1^{\prime}$ eau et environnement, p. 88. Faculté des sciences Rabat, Maroc (2009).

9. A. Taouraout, A. Chahlaoui, D. Belghity, M. Najy, A. Kharroubi, The socio-cultural acceptance of EcoSan latrines (UDDTs) in rural areas of Morocco. SCA '18, October 10-11, 2018, Tetouan, Morocco (C) 2018. Association for Computing Machinery. ACM ISBN 978-1 -4503-6562-8/18/10 ..\$15.00. (2018). https://doi.org/10.1145/3286606.3286815

10. Y.Guan, Y. Zhang, X. Huang, \& J. Fu, Effect of operating factors on the contaminants removal of a soil filter: multisoil-layering system. Environmental Earth Sciences, 74(3), 26792686 (2015). https://doi. org/10.1007/s12665-015-4288-8.

11. Rodier, Analyse de l'eau (eaux naturelles, eaux résiduaires, eau de mer) : physico-chimie, microbiologie, biologie, interprétation des résultats, 9ème édition, Dunod, Paris, 1 (2009).

12. H. Brix, Functions of macrophytes in constructed wetlands. Wat. Sci. Tech., 29, 71-78 (1994).

13. J. Vymazal, Plants used in constructed wetlands with horizontal subsurface flow: a review. Hydrobiologia 674, 133-156 (2011).

14. T. Saeed, and G. Sun, A review on nitrogen and organics removal mechanisms in subsurface flow constructed wetlands: Dependency on environmental parameters, operating conditions and supporting media: Journal of Environmental Management, v. 112, p. 429-448 (2012).

15. P. Molle, S. Prost-Boucle, \& A. Lienard, Potential for total nitrogen removal by combining vertical flow and horizontal flow constructed wetlands: A full-scale experiment study, Ecological Engineering, 34, 23-29 (2008).

16. L. Vera, G. Martel, \& M. Ma'rquez, Two years monitoring of the natural system for wastewater reclamation in Santa Luci'a, Gran Canaria Island. Ecological Engineering 50 (2013), 21. DOI: 10.1016/j. ecoleng.2012.08.001.

17. A. Morvannou, N. Forquet, S. Michel, S. Troesch, and P. Molle, Treatment performances of French constructed wetlands: Results from a database collected over the last 30 years, Water Science and Technology, 71, 1333-1339 (2015).

18. J. Paing, A. Guilbert, V. Gagnon, \& F. Chazarenc, Effect of climate, wastewater composition, loading rates, system age and design on performances of French vertical flow constructed wetlands: A survey based on 169 full scale systems, Ecological Engineering, 80, 46-52 (2015)..

19. F. Morari, L. Giardini, Municipal wastewater treatment with vertical flow constructed wetlands for irrigation reuse. Ecological Engineering 35, 643-653 (2009).

20. S.I. Abou-Elela, M.S. Hellal, Municipal wastewater treatment using vertical flow constructed wetlands planted with Canna, Phragmites and Cyperus. Ecol.Eng. 47, 209- 213 (2012).

21. Molle, P., Lie'nard, A., Boutin, C., Merlin, G., \& Iwema, A. (2005). How to treat raw sewage with constructed wetlands: an overview of the French systems. Water Science and Technology, 51(9), 11-21. 